\title{
Two Phase II randomized trials on the CRTh2 antagonist AZD I 98I in adults with asthma
}

This article was published in the following Dove Press journal:

Drug Design, Development and Therapy

31 August 2016

Number of times this article has been viewed

\section{Piotr Kuna' \\ Leif Bjermer ${ }^{2}$ \\ Göran Tornling 3,4}

'Department of Internal Medicine, Asthma and Allergy, Barlicki University Hospital, Medical University of Łódz, Łódz, Poland; 'Department of Respiratory Medicine and Allergology, Skane University Hospital, Lund University, ${ }^{3}$ AstraZeneca Research and Development, Molndal, ${ }^{4}$ Respiratory Medicine Unit, Department of Medicine Solna and CMM, Karolinska Institute and Karolinska University Hospital, Solna, Sweden
Correspondence: Piotr Kuna Department of Internal Medicine, Asthma and Allergy, Barlicki University Hospital, Medical University of Łódz, 90-I53 Łódz, Poland

Tel +48 426776834

Fax +4842678 II76

Email piotr.kuna@umed.lodz.pl
Background: Chemoattractant receptor-homologous molecule expressed on T helper type 2 (Th2) cell (CRTh2) receptor antagonists is being investigated for asthma.

Objectives: The aim of this study was to assess the effects of the CRTh2 receptor antagonist, AZD1981 (with/without inhaled corticosteroids [ICSs]), on lung function and asthma control.

Patients and methods: Adults aged 18-60 years were enrolled in two randomized, placebocontrolled, parallel-group trials (protocol number: D9830C00003 [study 1, n=209] and protocol number: D9830C00004 [study 2, n=510]). In study 1, patients with stable asthma (forced expiratory volume in 1 second $\left[\mathrm{FEV}_{1}\right]$ : $\left.65 \%-110 \%\right)$ were withdrawn from ICS $(<400 \mu \mathrm{g} / \mathrm{d})$ and randomized to AZD1981 1,000 mg twice daily (bid) or placebo. In study 2, patients with uncontrolled asthma $\left(\mathrm{FEV}_{1}: 40 \%-85 \%\right)$ despite ICS therapy ( $\left.\geq 500 \mu \mathrm{g} / \mathrm{d}\right)$ were randomized to $50 \mathrm{mg}, 400 \mathrm{mg}$, or 1,000 mg bid AZD1981 or placebo. The primary efficacy variable for both trials was the change in morning peak expiratory flow after 4 weeks of treatment. Secondary variables included Asthma Control Questionnaire (ACQ-5) scores, FEV 1 assessments, safety, and tolerability. In study 2, efficacy was also assessed according to atopic status.

Results: Following 4 weeks of treatment, there was a nonsignificant increase in morning peak expiratory flow on AZD1981 1,000 mg bid ( $9.5 \mathrm{~L} / \mathrm{min}$ vs placebo, $P=0.086$ [study 1] and $12 \mathrm{~L} / \mathrm{min}$ vs placebo, $P=0.16$ [study 2]). In study 2 , all doses of AZD1981 provided significant improvements in ACQ-5 scores (0.26-0.3 units vs placebo, $P=0.010-0.022)$; however, there was no dose-response relationship. Improved ACQ-5 scores and FEV $_{1}$ were observed in the majority of atopic patients treated with AZD1981. AZD1981 was well tolerated across treatment groups.

Conclusion: Further research may be warranted in atopic patients to fully evaluate the clinical efficacy of AZD1981.

Keywords: CRTh2 receptor, efficacy, Phase II, respiratory, Th2 cells, prostaglandin $\mathrm{D}_{2}$

\section{Introduction}

Asthma is a chronic inflammatory disease of the airways that affects $1 \%-18 \%$ of the population in different countries. ${ }^{1}$ Inhaled corticosteroids (ICSs) are currently recommended as first-line therapy for persistent asthma; ${ }^{1}$ however, many patients remain symptomatic despite treatment with moderate-to-high doses. ${ }^{2}$ As asthma is primarily an inflammatory disorder, add-on anti-inflammatory therapy in patients with suboptimally controlled airway inflammation remains an attractive area of research. The chemoattractant receptor-homologous molecule expressed on T helper type 2 (Th2) cells (CRTh2) is present on several cell types ${ }^{3-5}$ implicated in the inflammatory cascade in both allergic asthma and rhinitis. ${ }^{6}$

Prostaglandin $\mathrm{D}_{2}\left(\mathrm{PGD}_{2}\right)$ is the major ligand for this CRTh2 receptor and is also implicated in the pathophysiology of allergic asthma, with increased levels 
detected in the airways of patients with asthma following acute antigen challenge. ${ }^{7}$ High concentrations of $\mathrm{PGD}_{2}$ and CRTh2 receptor mRNA have also been found in the bronchoalveolar fluid of patients with severe, uncontrolled asthma, correlating with levels of blood eosinophils. ${ }^{8} \mathrm{PGD}_{2}$ is primarily produced by activated mast cells following challenge. ${ }^{3}$ Activation of the CRTh2 receptor by $\mathrm{PGD}_{2}$ leads to chemotaxis of Th2 lymphocytes, eosinophils, basophils, and mast cells, ${ }^{9-14}$ and to the production of proinflammatory cytokines. ${ }^{15-17} \mathrm{PGD}_{2}$ also heightens the activation of eosinophils, with respect to the respiratory burst and release of eosinophilic cationic protein, and may also delay eosinophilic and Th2 cell apoptosis. ${ }^{9,18,19}$ This accumulating evidence suggests that the CRTh2 receptor may play an important role in respiratory disease, since the blockade of the CRTh2 receptor significantly reduces experimental allergic airway inflammation. ${ }^{20-22}$ Evidence for the potential clinical efficacy of CRTh2 antagonists in patients with asthma or grass pollen allergies has also been provided by recent in vivo human studies. ${ }^{23-25}$

AZD1981 (AstraZeneca) is an oral, selective CRTh2 receptor antagonist, with the potential to inhibit the chemotaxis of primary Th 2 cells, eosinophils, and basophils, thereby hypothetically reducing the accumulation of these cells in the asthmatic lung. AZD1981 is a potent inhibitor of 13,14 di-hydro 15-keto $\mathrm{PGD}_{2}\left(\mathrm{DK}-\mathrm{PGD}_{2}\right.$ )-induced CD11b expression in human eosinophils. ${ }^{26}$

In this article, we report the results of the first two Phase II proof-of-principle clinical trials of AZD1981 administered for 4 weeks in patients with asthma. For study 1 , the primary objective was to evaluate the efficacy of twice daily (bid), orally administered AZD1981 monotherapy compared with placebo over a 4-week treatment period in patients with stable asthma who were withdrawn from ICS. Secondary objectives included safety and tolerability, as well as pharmacokinetics and assessment of eosinophil counts. For study 2, the primary objective was to evaluate the efficacy of AZD1981 compared with placebo in patients with asthma who were still symptomatic despite treatment with moderate-to-high doses of ICS. Secondary objectives of study 2 included safety and tolerability and dose response. As the CRTh2 receptor is implicated in the allergic asthma cascade, a post hoc analysis was also carried out in study 2 to assess the efficacy of AZD1981 in patients with atopic asthma. The hypothesis of both studies was that treatment with AZD1981 taken as oral tablets improves lung function more effectively than placebo, based on morning peak expiratory flow (PEF).

\section{Patients and methods}

\section{Ethics}

This study was approved by the Bioethics Commission of the Medical University of Łódź (Łódź, Poland), as well as each relevant national, regional, or independent ethics committee or institutional review boards. It was conducted in accordance with the Declaration of Helsinki 2008 and Good Clinical Practice guidelines. Informed consent was obtained from all subjects prior to initiation of any studyspecific procedures.

\section{Study design, treatment, and patients Study I}

Following a 3-week run-in to establish the existence of stable asthma on low-dose ICS ( $\leq 400 \mu \mathrm{g} / \mathrm{d})$, this 4-week, multicenter, randomized, double-blind, parallel-group, placebo-controlled study assessed the efficacy and tolerability of a supramaximal dose of AZD1981 (1,000 mg bid oral suspension), following the withdrawal of all ICSs on the day of randomization (protocol number: D9830C00003; EudraCT number: 2006-001193-25). Patients were randomized in blocks of 55 using a computerized randomization code to AZD1981 or matching placebo. All patients in both groups had access to a short-acting $\beta_{2}$-agonist reliever, terbutaline (Bricanyl ${ }^{\mathrm{TM}}$ Turbuhaler $^{\mathrm{TM}}, 0.5 \mathrm{mg} /$ dose [AstraZeneca]), as needed during the run-in and treatment phase of the trial. During the treatment period, clinic visits occurred weekly for the first 2 weeks, followed by a final on-treatment visit after 2 weeks.

Patients eligible for inclusion were male and female patients who were in the age group of 18-60 years with persistent asthma of $\geq 6$-month duration, were treated with any ICS $(\leq 400 \mu \mathrm{g} / \mathrm{d})$, were stable at the time of screening to baseline, had a forced expiratory volume in 1 second $\left(\mathrm{FEV}_{1}\right) 65 \%-110 \%$ of predicted normal, had reversible airway obstruction (increase in $\mathrm{FEV}_{1}$ of $\geq 12 \%$ vs baseline and $\geq 200 \mathrm{~mL}$ after an inhalation of $1 \mathrm{mg}$ terbutaline), had no clinically important asthma exacerbations during the month before visit 1 or during the run-in period, and had a positive skin prick test to at least one airway allergen (eg, pollen from birch, grass, or mugwort; animal fur such as dog, cat, horse, or house dust mite) at visit 1 or within prior 2 years. Female patients were of non-childbearing potential.

Exclusion criteria included an inability to tolerate the withdrawal of asthma therapy as required for the study, hospitalization for asthma within the last 2 years prior to visit 1 , respiratory infection significantly affecting asthma symptoms (as judged by the investigator) within 30 days prior to visit 1 , 
a history of smoking of more than ten pack-years, a body mass index of $<18 \mathrm{~kg} / \mathrm{m}^{2}$, and body weight of $<50 \mathrm{~kg}$.

\section{Study 2}

This was a 4-week, multicenter, randomized, double-blind, placebo-controlled, parallel dose-range finding study to assess the efficacy and tolerability of AZD1981 in patients with asthma inadequately controlled on existing ICS (protocol number: D9830C00004, ClinicalTrials.gov identifier: NCT00758589). Patients continued to receive ICS for the duration of the trial. Eligible patients entered a 2-week run-in period, during which any long-acting $\beta_{2}$-agonists were withdrawn. Eligible patients symptomatic on ICS alone were then randomized in blocks of 90-95 using a computerized randomization list to one of four treatment groups: 1) AZD1981 $50 \mathrm{mg} /$ dose - one AZD1981 $50 \mathrm{mg}$ tablet and three placebo tablets bid; 2) AZD1981 $400 \mathrm{mg} /$ dose - one AZD1981 $250 \mathrm{mg}$ tablet and three AZD1981 $50 \mathrm{mg}$ tablets bid; 3) AZD1981 1,000 mg/dose - four AZD1981 $250 \mathrm{mg}$ tablets bid; 4) placebo - four placebo tablets bid. Patients who received terbutaline $(0.5 \mathrm{mg} /$ dose $)$ or any alternative inhaled short-acting $\beta_{2}$-agonists (eg, salbutamol) as reliever medication throughout the study. Clinic visits occurred every 2 weeks during the treatment period.

Patients eligible for inclusion were male and female patients aged 18-60 years with persistent asthma of $\geq 6$-month duration and who had been prescribed daily use of ICS for $\geq 3$ months prior to visit 1 at a dose of $\geq 500 \mu \mathrm{g} / \mathrm{d}$ of budesonide, ciclesonide, mometasone, fluticasone, or $\geq 1,000 \mu \mathrm{g} / \mathrm{d}$ beclomethasone dipropionate. Other inclusion criteria included prebronchodilator $\mathrm{FEV}_{1} 40 \%-85 \%$ of predicted normal, reversible airway obstruction (increase in $\mathrm{FEV}_{1}>12 \%$ vs baseline or $>200 \mathrm{~mL}$ after inhalation of $400 \mu \mathrm{g}$ salbutamol or $1 \mathrm{mg}$ terbutaline), and use of reliever medication for symptom relief on at least 4 of the last 7 days of the run-in period. Exclusion criteria were the same as for study 1, except current smokers who were allowed, and there was no restriction on BMI or body weight (kilogram). Smokers were included in study 2, so that patients on AZD1981 were more representative of the real-world population.

\section{Efficacy evaluations for both studies}

The primary efficacy variable in both trials was the change in morning PEF from baseline after 4 weeks on treatment relative to placebo (study 1: difference between the mean of 4-week treatment period and the mean of the last 10 days of the run-in period; study 2: difference between the last measurement during treatment and last baseline measurement).
All morning PEFs were measured by patients at home using a peak flow meter immediately upon waking, after clearing out mucus, and before taking the morning dose of AZD1981. Three assessments were made while standing and patients recorded the highest value in an eDiary. Each patient received verbal training and written instructions in the correct use of the peak flow meter and in eDiary completion at the baseline visit and was to use the same meter throughout the study, if possible.

Secondary efficacy variables included in both trials were evening PEF (taken 12 hours after the morning assessment and before the evening dose), use of reliever medication, reliever medication-free days, asthma symptom score, nights with awakenings due to asthma symptoms, symptom-free days, asthma control days (defined as a day and night with no asthma symptoms, no awakenings due to asthma, and no use of reliever medication), $\mathrm{FEV}_{1}$ and $\mathrm{FVC}$ measured in the clinic, and asthma control assessed using the 5-point Asthma Control Questionnaire (ACQ-5). An additional secondary efficacy variable included in study 1 was the number of eosinophils in induced sputum (optional). Additional secondary efficacy variables in study 2 included morning and evening $\mathrm{FEV}_{1}$ registered by a home spirometer and a post hoc analysis of AZD1981 adjuvant efficacy in atopic patients. Atopic status was determined at visit 3 by Phadiatop ${ }^{\mathrm{TM}}$ test (Phadia AB, Uppsala, Sweden; positive = atopic, negative $=$ nonatopic).

\section{Safety evaluations for both studies}

Adverse events (AEs), serious AEs (SAEs), and other significant AEs were recorded at the follow-up visits, including details of the nature, incidence, and severity of AEs. AEs were coded using the Medical Dictionary for Regulatory Activities and the relationship of all AEs to treatment was assessed by the investigators. Patients were also followed up via telephone 2 weeks after the last dose to record any AEs that had occurred during the 2-week period. Hematology, clinical chemistry, urinalysis, electrocardiogram (ECG), pulse, and blood pressure were also included in the safety and tolerability assessments.

\section{Pharmacokinetic and pharmacodynamic evaluations for both studies}

The assessment of pharmacokinetic parameters was a secondary end point in study 1 only. Blood samples were taken from all patients at visits 4 and 5 before and 2-4 hours after a dose of AZD1981 for pharmacokinetic evaluation. Samples were analyzed using a validated protein precipitation 
and high-performance liquid chromatography (HPLC)/mass spectrometry(MS)/MS method with a lower limit of quantification of $20 \mathrm{nM}$. Assessments included area under the plasma concentration-time curve over the dosing interval (area under the curve, $\left.\mathrm{AUC}_{t}\right)$, maximum concentration $\left(C_{\max }\right)$, minimum concentration $\left(C_{\min }\right)$, time to maximum concentration $\left(t_{\max }\right)$, and oral clearance (CL/F) of AZD1981.

The assessment of pharmacodynamic parameters was exploratory end points for both studies. In study 1 , blood eosinophils and fractional exhaled nitric oxide were assessed at visits 2, 4, and 5. In study 2, blood samples were taken at visits 3 and 5 to assess plasma levels of $4 \beta$-hydroxycholesterol to investigate the CYP3A4 induction of AZD1981. Other assessments in study 2 included testing for markers of inflammation by enzyme-linked immunosorbent assay (eg, interleukin [IL]-13, IL-10, IL-6, tumor necrosis factor; data not shown).

\section{Statistical analysis and sample size for both studies}

All randomized patients with available data were included in the safety and efficacy analysis (full analysis set). The primary and secondary outcome variables were analyzed using an analysis of variance model with treatment and country as factors and baseline measurement as covariate. Country was used as a covariate, rather than center, as there were many small centers, and the analysis would have weighted results from individual centers equally. In study 1 , a sample size of 55 patients in each group was determined to have an $80 \%$ chance of detecting a true difference on morning PEF of $24 \mathrm{~L} / \mathrm{min}$ between the treatment groups, assuming a standard deviation of $45 \mathrm{~L} / \mathrm{min}$, using a two-sided test with a significance level of 0.05 . In study 2 , a sample size of 320 patients, 80 in each treatment group, was determined to have $80 \%$ power to detect a difference on morning PEF of $18 \mathrm{~L} / \mathrm{min}$ between AZD1981 and placebo, assuming a common standard deviation of $45 \mathrm{~L} / \mathrm{min}$, using a one-sided test with a significance level of 0.05 . A post hoc analysis was carried out on morning PEF, FEV ${ }_{1}$ measured in the clinic, and ACQ-5 scores in atopic patients. The statistical model for this post hoc analysis was extended to include a factor for atopic status of patients by the result of a Phadiatop ${ }^{\mathrm{TM}}$ test (positive $=$ atopic, negative $=$ nonatopic) and its interaction with treatment.

\section{Results}

Patients

\section{Study I}

A total of 209 patients with stable persistent asthma were screened at 21 centers in Denmark, Germany, Poland, Sweden, and the UK, of whom 113 were randomized and 98 completed the study (Figure 1). Reasons for discontinuation are described in Figure 1. The first patient entered the study on September 4, 2006, and the last patient finished the study on August 2, 2007. The two treatment groups were well balanced in terms of demographic and baseline disease characteristics (Table 1).

\section{Study 2}

A total of 510 patients with moderate-to-severe asthma were screened at 30 centers in Argentina, Brazil, Costa Rica, and Poland, of whom 368 were allocated to treatment and 350 completed the study (Figure 1). Reasons for discontinuation are described in Figure 1. The first patient entered the study on September 16, 2008, and the last patient finished the study on July 13, 2009. The four treatment groups had similar baseline characteristics on average (Table 1).

Self-reported medication use was high and consistent between treatment groups in both studies, with $90 \%$ of patients taking $\geq 98 \%$ of their total daily study medication.

\section{Efficacy of AZD I 98 I}

\section{Study I}

Following 4 weeks of treatment, AZD1981 had a nonsignificant effect on mean morning PEF (primary end point), which was estimated to be $9.5 \mathrm{~L} / \mathrm{min}$ vs placebo $(P=0.086)$. This trend for improvement over the 4 weeks of the study appeared to reflect a gradual decrease in lung function in patients on placebo and unchanging lung function in patients on AZD1981 following the withdrawal of ICS (Figure 2 and Table 2). Secondary outcome variables showed numerical improvements in lung function and asthma control (Figure 3 and Table 3). However, these differences were small and not statistically significant.

\section{Study 2}

Following 4 weeks of treatment with AZD1981, there was no significant effect vs placebo on the primary efficacy outcome of morning PEF (Figure 2), or on the majority of the secondary efficacy variables, apart from ACQ-5 scores assessed at the clinic (Table 3). For lung function measured at the clinic, only the AZD1981 $400 \mathrm{mg}$ group showed any significant effect on clinic $\mathrm{FEV}_{1}$ vs placebo $(P=0.015)$, although there were numerical increases in $\mathrm{FEV}_{1}$ at other doses (Figure 3).

For the post hoc analysis of efficacy according to atopic status, around $72 \%$ of patients in the study 2 population were atopic (positive Phadiatop ${ }^{\mathrm{TM}}$ test). Of those patients who were found to be atopic, 68 patients were randomized 


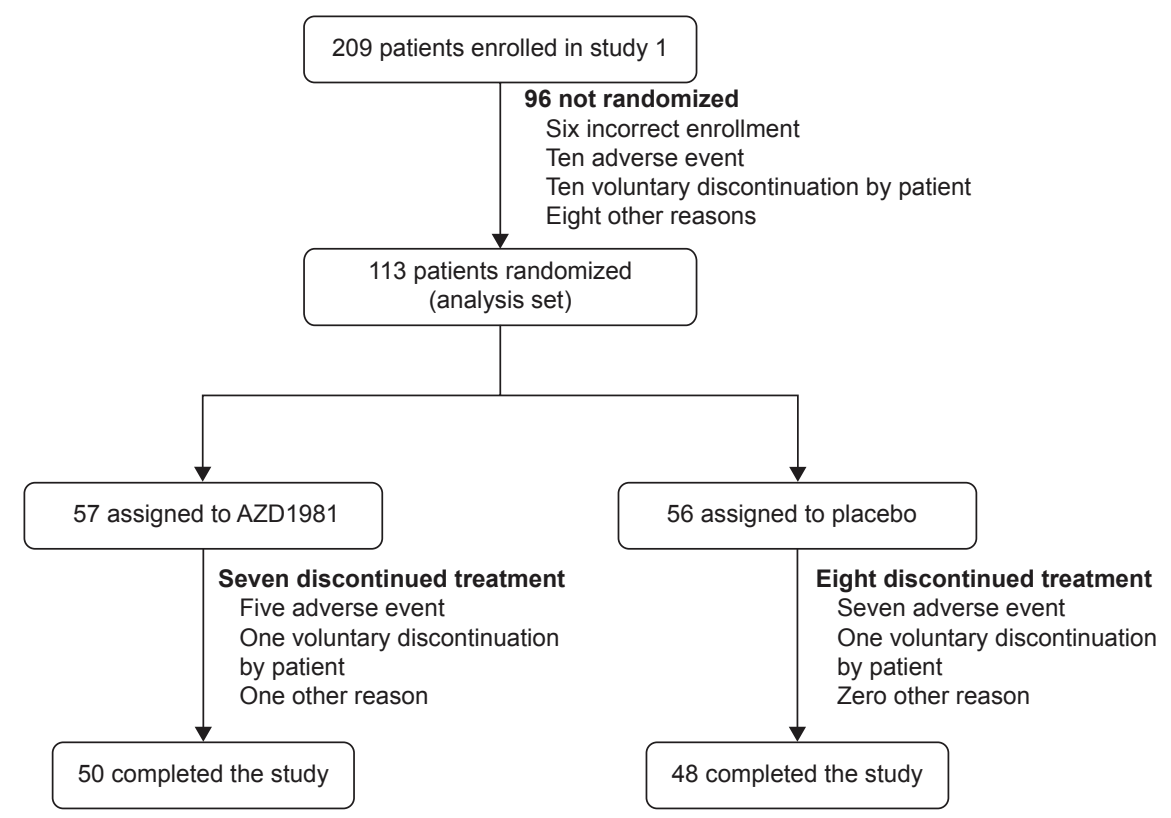

B
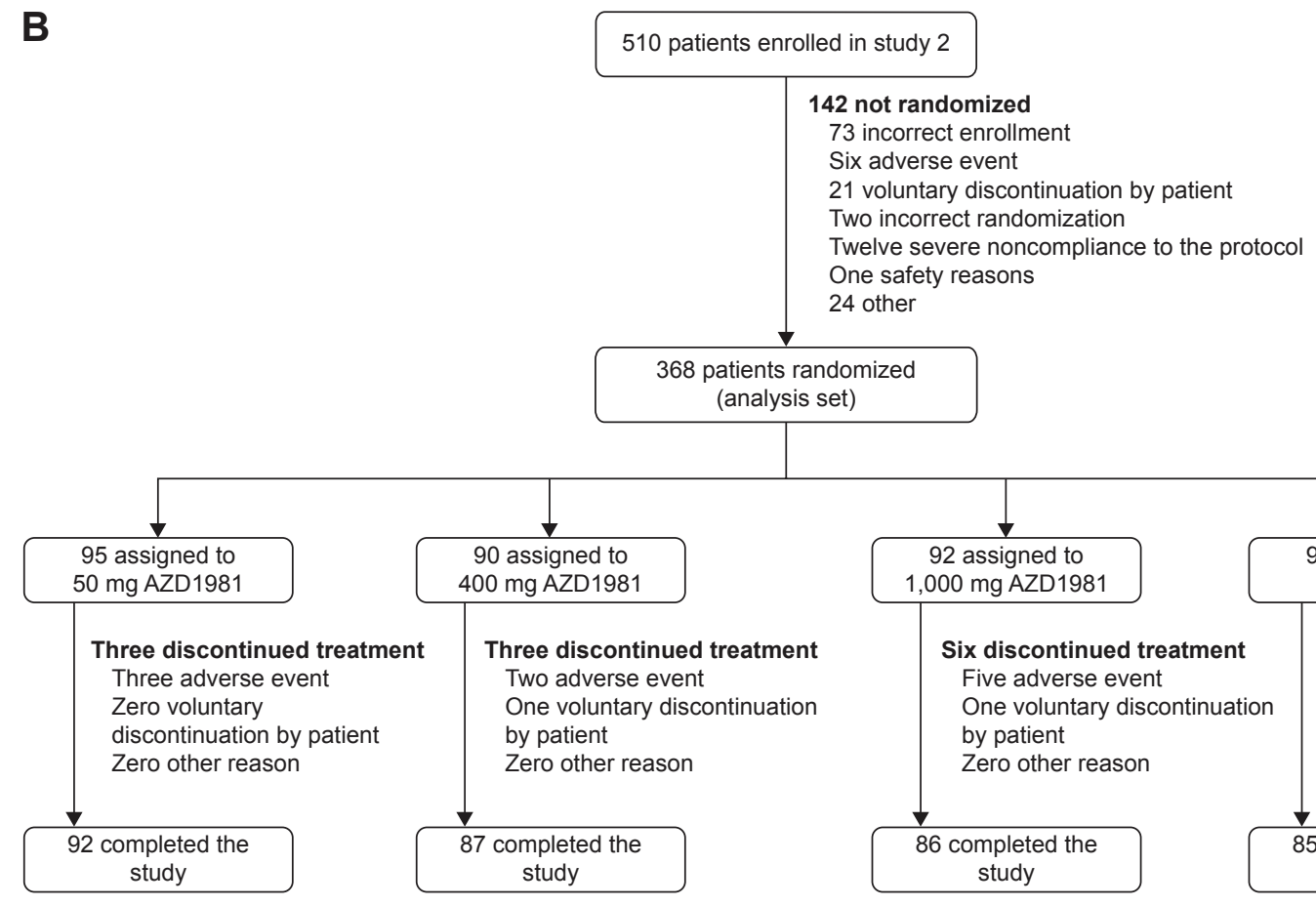

Figure I Flowchart of study I (A) and study 2 (B).

to $50 \mathrm{mg}$ active treatment group, 69 patients to the $400 \mathrm{mg}$ active treatment group, 59 patients to the $1,000 \mathrm{mg}$ active treatment group, and 69 patients were randomized to receive placebo. In atopic patients, AZD1981 was associated with an improvement in ACQ-5 scores vs placebo (decreases of 0.42 units for $50 \mathrm{mg}, 0.40$ units for $400 \mathrm{mg}$, and 0.38 units for $1,000 \mathrm{mg}$ ), while no effect was seen in the nonatopic group. Similarly, clinic $\mathrm{FEV}_{1}$ in atopic patients showed an increase of $\sim 170-180 \mathrm{~mL}$ in the two highest dose groups (Table 4).

\section{Safety and tolerability of AZD I98I} Study I

A similar proportion of patients in the active treatment and placebo groups reported AEs (51\% vs 46\%), mainly infections and respiratory disorders, of mild-to-moderate intensity. Asthma and nasopharyngitis were the most common AEs (Table 5). The incidence of AEs of severe intensity was low and similar between the two treatment groups. No deaths were reported during this study. There were two SAEs, both 
Table I Demographics of subjects randomized in study I and study 2

\begin{tabular}{|c|c|c|c|c|c|c|}
\hline \multirow[t]{3}{*}{ Characteristic } & \multicolumn{2}{|l|}{ Study I } & \multicolumn{4}{|l|}{ Study 2} \\
\hline & \multirow{2}{*}{$\begin{array}{l}\text { AZD I 98I } \\
\text { I,000 mg bid } \\
(n=57)\end{array}$} & \multirow[t]{2}{*}{ Placebo $(n=56)$} & \multicolumn{3}{|l|}{ AZDI98I } & \multirow[t]{2}{*}{ Placebo $(n=91)$} \\
\hline & & & $\begin{array}{l}50 \mathrm{mg} \text { bid } \\
(\mathrm{n}=95)\end{array}$ & $\begin{array}{l}400 \mathrm{mg} \text { bid } \\
(\mathrm{n}=90)\end{array}$ & $\begin{array}{l}\mathrm{I}, 000 \mathrm{mg} \text { bid } \\
(\mathrm{n}=92)\end{array}$ & \\
\hline Mean age, years & 38.4 & 39.0 & 43.3 & 43.0 & 43.5 & 45.7 \\
\hline Female sex, n (\%) & $9(16)$ & $9(16)$ & $27(28)$ & $19(21)$ & $34(37)$ & $33(36)$ \\
\hline \multicolumn{7}{|l|}{ Race, n (\%) } \\
\hline White & $56(98)$ & $56(100)$ & $88(93)$ & $84(93)$ & $83(90)$ & $82(90)$ \\
\hline Black & & & 0 & $I(I)$ & $\mathrm{I}(\mathrm{I})$ & $\mathrm{I}(\mathrm{I})$ \\
\hline Asian/oriental & I (2) & 0 & 0 & $\mathrm{I}(\mathrm{I})$ & 0 & 0 \\
\hline Other & & & $7(7)$ & $4(4)$ & $8(9)$ & $8(9)$ \\
\hline $\mathrm{BMI}, \mathrm{kg} / \mathrm{m}^{2}$ & 26.3 & 26.7 & 26.9 & 27.0 & 27.2 & 27.6 \\
\hline Median time since diagnosis, years & 13 & 13 & 11.1 & 12.1 & 10 & 14.9 \\
\hline \multicolumn{7}{|l|}{ Smoking status, $\mathrm{n}(\%)$} \\
\hline Never & $43(75)$ & $45(80)$ & $77(8 \mathrm{I})$ & $79(88)$ & $80(87)$ & $78(86)$ \\
\hline Previous & $14(25)$ & $9(16)$ & $16(17)$ & $10(11)$ & $10(11)$ & $12(13)$ \\
\hline Occasional & 0 & $2(4)$ & & & & \\
\hline Current & & & $2(2 \%)$ & $\mathrm{I}(\mathrm{I})$ & $2(2)$ & $\mathrm{I}(\mathrm{I})$ \\
\hline ICS dose at entry, $\mu g^{\mathrm{a}}$ & 305.1 & 312.3 & 721 & 744 & 693 & 735 \\
\hline FEV , pre-bronchodilator, L & 3.2 & 3.2 & 2.30 & 2.43 & 2.29 & 2.14 \\
\hline $\mathrm{FEV}_{1}, \% \mathrm{PN}$ & 82.6 & 82.0 & 66.2 & 68.5 & 69.0 & 66.4 \\
\hline FEV, post-bronchodilator, $\mathrm{L}$ & 3.7 & 3.6 & 2.90 & 2.98 & 2.88 & 2.72 \\
\hline FVC, L & 4.4 & 4.5 & 3.42 & 3.58 & 3.27 & 3.20 \\
\hline Mean no relievers/as needed, use daily & 2.0 & 2.2 & 3.35 & 3.17 & 3.28 & 3.62 \\
\hline Awakenings, $\%$ & 6.7 & 6.9 & 50.9 & 42.4 & 44.3 & 48.4 \\
\hline Phadiatop test & Not tested & Not tested & & & & \\
\hline Negative = nonatopic $(\%)$ & & & $27(28)$ & $20(22)$ & $31(34)$ & $22(27)$ \\
\hline Positive = atopic $(\%)$ & & & $68(72)$ & $69(77)$ & $59(64)$ & $69(72)$ \\
\hline
\end{tabular}

Notes: any ICS. Study I was a 4-week, randomized, placebo-controlled study that assessed the efficacy and tolerability of a supra-maximal dose of AZDI98I in patients with stable asthma. Study 2 was a 4-week, randomized, placebo-controlled dose-range finding study that assessed the efficacy and tolerability of AZDI98I in patients with asthma not controlled on ICS.

Abbreviations: bid, twice daily; BMI, body mass index; ICS, inhaled corticosteroids; FEV , forced expiratory volume in I second; FVC, forced vital capacity; PN, predicted normal.
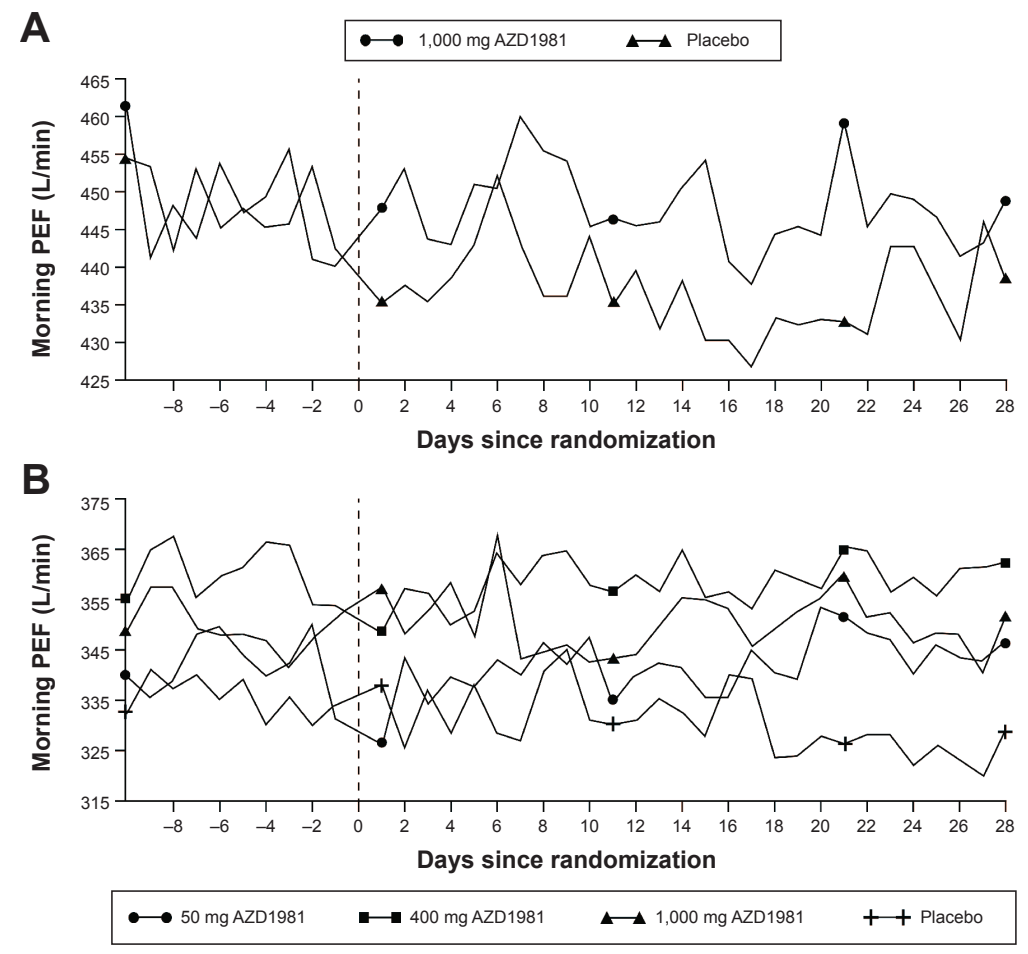

Figure 2 Daily mean morning PEF for study I (A) and study 2 (B) over the 4 weeks of each study (absolute values).

Notes: Study I was a 4-week, randomized, placebo-controlled study that assessed the efficacy and tolerability of a supra-maximal dose of AZDI98I in patients with stable asthma. Study 2 was a 4-week, randomized, placebo-controlled dose-range finding study that assessed the efficacy and tolerability of AZDI98I in patients with asthma not controlled on ICS.

Abbreviation: PEF, peak expiratory flow. 
Table 2 Efficacy variables in study I during the run-in period and after 4 weeks of treatment with AZDI98I I,000 mg bid or placebo

\begin{tabular}{|c|c|c|c|c|}
\hline \multirow[t]{2}{*}{ Outcome } & \multicolumn{2}{|l|}{ AZDI98I (n=57) } & \multicolumn{2}{|l|}{ Placebo $(n=56)$} \\
\hline & Run-in & Treatment & Run-in & Treatment \\
\hline \multicolumn{5}{|l|}{ Primary } \\
\hline Morning PEF, mean (SD) & $449(116)$ & $449(115)$ & $448(103)$ & $438(107)$ \\
\hline \multicolumn{5}{|l|}{ Secondary } \\
\hline Evening PEF, mean (SD) & $472(12 \mid)$ & $466(119)$ & $469(99)$ & $456(104)$ \\
\hline PEF variability, \% (SD) & $9.82(5.39)$ & $9.65(4.80)$ & $10.3(4.99)$ & $10.4(4.96)$ \\
\hline $\begin{array}{l}\text { Reliever medication taken over } 24 \text { hours, number } \\
\text { of inhalations (SD) }\end{array}$ & $2.04(1.29)$ & $1.91(1.60)$ & $2.15(1.29)$ & $2.22(1.65)$ \\
\hline Reliever medication-free days, number of days (SD) & $17.40(23.89)$ & $25.13(29.55)$ & $11.74(16.45)$ & $17.23(23.46)$ \\
\hline Total asthma symptom score & $\mathrm{I} .53(0.70)$ & $1.49(0.80)$ & $1.66(0.73)$ & $1.65(0.82)$ \\
\hline Awakenings (\%) & $6.74(10.23)$ & $4.53(8.29)$ & $6.89(15.56)$ & $6.57(9.67)$ \\
\hline Symptom-free days (\%) & I5.47 (25.24) & $16.55(25.93)$ & $10.49(20.51)$ & $12.74(21.96)$ \\
\hline Asthma control days (\%) & $9.41(17.95)$ & $10.24(20.57)$ & $4.64(11.44)$ & $7.23(15.25)$ \\
\hline Sputum eosinophil counts, $10^{6} / g$ (range) & $0.024(0.00-0.53)$ & $0.004(0.00-0.53)$ & $0.033(0.00-1.21)$ & $0.014(0.00-0.73)$ \\
\hline $\mathrm{FEV}_{1 \text { pre }}, \mathrm{L}(\mathrm{SD})^{\mathrm{a}}$ & $3.20(1.2-4.7)$ & $3.27(1.0-4.9)$ & $3.17(1.8-5.1)$ & $3.19(1.2-5.0)$ \\
\hline $\mathrm{FEV}_{1 \text { post' }}, \mathrm{L}(\mathrm{SD})^{\mathrm{a}}$ & $3.67(1.5-5.1)$ & $3.57(1.3-5.3)$ & $3.6 \mathrm{I}(2.1-5.3)$ & $3.55(1.6-5.4)$ \\
\hline FVC, L (SD) & $4.37(1.9-6.4)$ & $4.51(1.6-6.6)$ & $4.47(2.6-6.9)$ & $4.48(1.8-7.1)$ \\
\hline
\end{tabular}

Notes: aMeasured in the clinic at baseline and after 4 weeks of treatment. 'Sputum eosinophils were measured in nine patients who received AZDI98I and I3 patients who received placebo. Study I was a 4-week, randomized, placebo-controlled study that assessed the efficacy and tolerability of a supra-maximal dose of AZDI98I in patients with stable asthma.

Abbreviations: bid, twice daily; FEV , forced expiratory volume in I second; FVC, forced vital capacity; PEF, peak expiratory flow; SD, standard deviation.

experienced by patients receiving placebo (conjunctivitis $[n=1]$ and lower respiratory tract infection $[n=1])$, neither of which was considered treatment related. More patients discontinued due to an $\mathrm{AE}$ in the placebo group (13\%) than in the AZD1981 group (9\%). The most common AE leading to discontinuations was asthma (four patients in each treatment group). No consistent changes in safety laboratory variables, vital signs, ECG, or physical examination were observed, although a small number of patients receiving AZD1981 had slightly elevated alanine aminotransferase
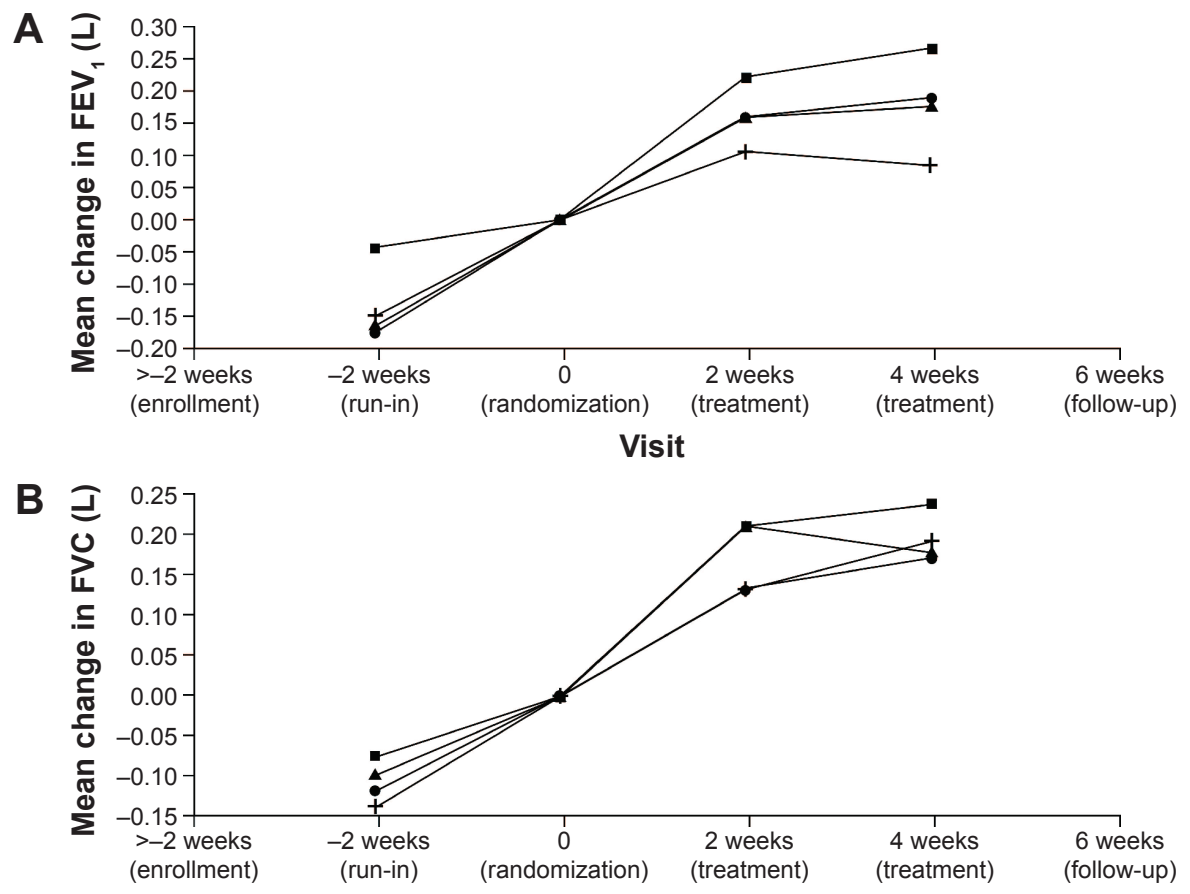

Visit

$$
\bullet 50 \mathrm{mg} \mathrm{AZD1981} 400 \mathrm{mg} \mathrm{AZD1981} \longleftrightarrow 1,000 \mathrm{mg} \mathrm{AZD1981} \mathrm{+}+\text { Placebo }
$$

Figure 3 Effect of AZDI98I on FEV $(\mathbf{A})$ and FVC (B) measured at the clinic during the 4-week study period in study 2.

Note: Study 2 was a 4-week, randomized, placebo-controlled dose-range finding study that assessed the efficacy and tolerability of AZDI98I in patients with asthma not controlled on ICS.

Abbreviations: FEV , forced expiratory volume in I second; FVC, forced vital capacity. 


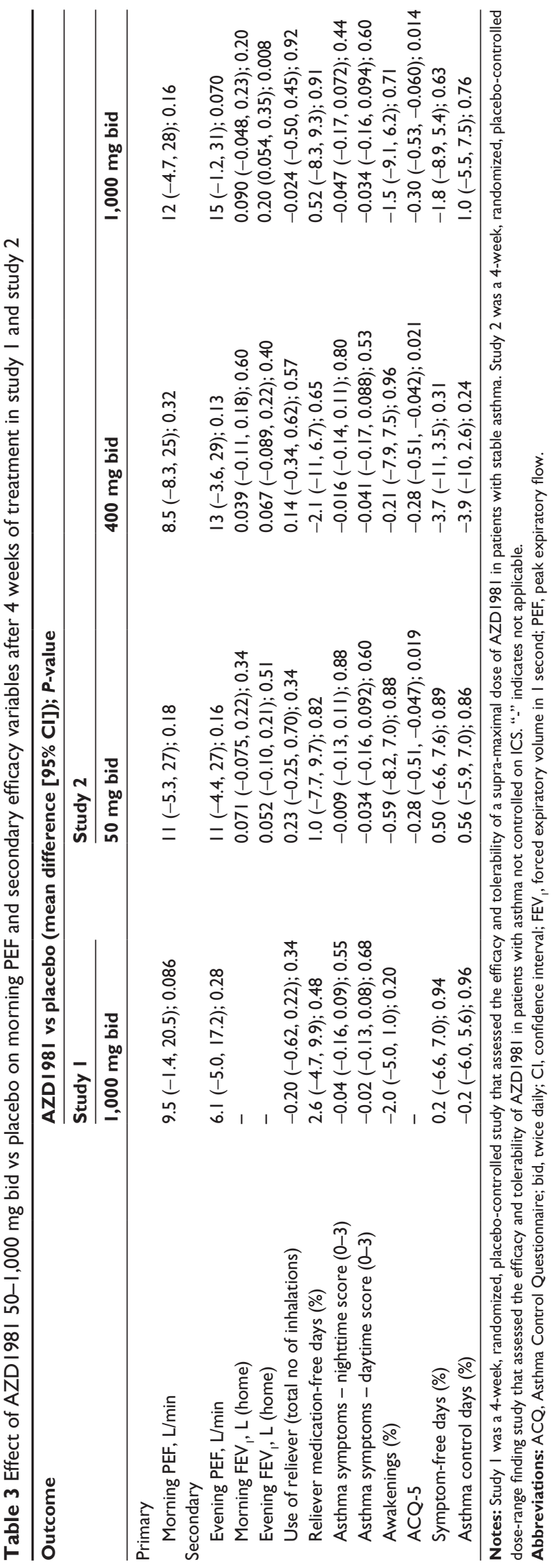

and thyroid-stimulating hormone values at the end of the treatment period.

\section{Study 2}

The most frequently reported AEs were headache, gastritis, asthma, upper respiratory tract infection, nasopharyngitis, influenza, abdominal pain, and pharyngitis. A slightly higher incidence of gastritis was observed in the $1,000 \mathrm{mg}$ group, compared with the other treatment doses of AZD1981. AEs reported by at least $2 \%$ of patients are shown in Table 6 . In total, 14 patients (4\%) withdrew from the study due to an AE: three (3\%), two (2\%), and five (5\%) in the AZD1981 $50 \mathrm{mg}, 400 \mathrm{mg}$, and $1,000 \mathrm{mg}$ treatment groups, respectively, and four (4\%) in the placebo group. Two patients experienced an SAE during the 4-week treatment period: one patient in the 1,000 mg treatment group (acute cholelithiasis) and one in the placebo group (dyspnea).

\section{Pharmacokinetic and pharmacodynamic assessments}

\section{Study I}

The pharmacokinetic profile of AZD1981 was similar to that previously seen in healthy volunteers during Phase I trials (unpublished data), with an approximate steady state reached within 2 weeks of treatment. $T_{\text {max }}$ (arithmetic mean) was reached at 150 minutes and 240 minutes at visits 2 and 5, respectively; $C_{\max }$ (geometric mean) at visits 2 and 5 was $13,875 \mathrm{nM}$ (coefficient of variation [CV], 57.8) and 8,983 nM $(\mathrm{CV}, 69.7)$ respectively; $C_{\min }$ (geometric mean) was $1,444 \mathrm{nM}$ (CV:42.7), and CL/F was $50.15 \mathrm{~L} / \mathrm{h}(\mathrm{CV}: 54.9)$ at visit 5.

AZD1981 had no significant effect on blood eosinophils or exhaled nitric oxide over the course of the study (Table 2).

\section{Study 2}

Increases in $4 \beta$-hydroxycholesterol up to $57 \%$ were seen with the two higher doses of AZD1981, indicating that AZD1981 has the potential for cytochrome P450 induction (eg, CYP3A4).

\section{Discussion}

The two studies described were the first clinical investigations of the CRTh2 receptor antagonist AZD1981 conducted in patients with asthma. In both studies, there was a nonsignificant effect of AZD1981 on morning PEF (the primary efficacy variable). In study 1 , which was performed in patients with stable asthma on existing ICS, a lack of any pronounced deterioration in lung function on the withdrawal of all ICSs in the placebo group limited the ability to detect the efficacy in 
Table 4 Effect of AZD 198I 50-1,000 mg bid vs placebo on the change in FEV, measured in the clinic and ACQ-5 in all patients, atopic patients, and nonatopic patients from study 2

\begin{tabular}{|c|c|c|c|c|}
\hline \multirow[t]{2}{*}{ Population } & \multirow[t]{2}{*}{ Variable } & \multicolumn{3}{|c|}{ AZD I 98 I vs placebo (mean difference $[95 \% \mathrm{CI}]$ ) } \\
\hline & & $50 \mathrm{mg}$ bid & $400 \mathrm{mg}$ bid & I,000 mg bid \\
\hline \multirow[t]{2}{*}{ All patients } & $\mathrm{FEV}_{1}(\mathrm{~L})$ & $0.10(-0.042,0.25)$ & $0.18(0.0036,0.33)$ & $0.095(-0.050,0.24)$ \\
\hline & ACQ-5 & $-0.28(-0.5 \mathrm{I},-0.047)$ & $-0.28(-0.51,-0.042)$ & $-0.30(-0.53,-0.060)$ \\
\hline \multirow[t]{2}{*}{ Atopic patients } & $\mathrm{FEV}_{1}(\mathrm{~L})$ & $0.13(-0.043,0.30)$ & $0.18(0.014,0.35)$ & $0.17(-0.006,0.34)$ \\
\hline & ACQ-5 & $-0.42(-0.69,-0.15)$ & $-0.40(-0.67,-0.13)$ & $-0.38(-0.67,-0.096)$ \\
\hline \multirow[t]{2}{*}{ Nonatopic patients } & $\mathrm{FEV}_{1}(\mathrm{~L})$ & $0.035(-0.25,0.32)$ & $0.21(-0.089,0.5 \mathrm{I})$ & $-0.039(-0.3 \mathrm{I}, 0.23)$ \\
\hline & ACQ-5 & $0.095(-0.36,0.55)$ & $0.10(-0.38,0.58)$ & $-0.031(-0.47,0.40)$ \\
\hline
\end{tabular}

Note: Study 2 was a 4-week, randomized, placebo-controlled dose-range finding study that assessed the efficacy and tolerability of AZDI98I in patients with asthma not controlled on ICS.

Abbreviations: ACQ, Asthma Control Questionnaire; bid, twice daily; Cl, confidence interval; FEV , forced expiratory volume in I second; FVC, forced vital capacity.

this setting. In study 2, which was performed in patients with uncontrolled asthma on concomitant ICS, doses of AZD1981 tested showed significant improvements in asthma control and $\mathrm{FEV}_{1}$ assessed at the clinic, with slightly greater effects detected in the atopic subgroup of patients (post hoc analysis).

Table 5 Summary of AEs reported in study I

\begin{tabular}{|c|c|c|}
\hline n (\%) & $\begin{array}{l}\text { AZD I 98I } \\
(n=57)\end{array}$ & $\begin{array}{l}\text { Placebo } \\
(n=56)\end{array}$ \\
\hline Any AE & $29(5 I)$ & $26(46)$ \\
\hline \multicolumn{3}{|l|}{ AEs reported by $\geq 2 \%$ patients } \\
\hline Asthma & $5(9)$ & $5(9)$ \\
\hline Nasopharyngitis & $3(5)$ & $7(13)$ \\
\hline Increased urinary alpha I microglobulin & $2(4)$ & I (2) \\
\hline Allergic rhinitis & $2(4)$ & 0 \\
\hline Pyrexia & I (2) & I (2) \\
\hline Pharyngitis & I (2) & I (2) \\
\hline Neurosis & I (2) & I (2) \\
\hline Diarrhea & $I(2)$ & I (2) \\
\hline Lower respiratory tract infection & I (2) & I (2) \\
\hline Headache & I (2) & I (2) \\
\hline Cough & I (2) & I (2) \\
\hline Dyspnea & $I(2)$ & I (2) \\
\hline Dyspepsia & I (2) & I (2) \\
\hline Conjunctivitis & 0 & $2(4)$ \\
\hline Allergic dermatitis & 0 & $2(4)$ \\
\hline Anxiety & 0 & $2(4)$ \\
\hline Eczema & $2(4)$ & 0 \\
\hline Upper respiratory tract infection & I (2) & I (2) \\
\hline Withdrawals due to AEs & $5(9)$ & $7(\mid 3)$ \\
\hline Severe lower respiratory tract & 0 & I (2) \\
\hline \multicolumn{3}{|l|}{ infection } \\
\hline Asthma & $4^{a}(7)$ & $4(7)$ \\
\hline Drug eruption & $I^{a}(2)$ & 0 \\
\hline Pneumonia & 0 & I (2) \\
\hline Diarrhea & I (2) & 0 \\
\hline Allergic dermatitis & 0 & I (2) \\
\hline $\begin{array}{l}\text { Number of AEs considered causally } \\
\text { related to treatment }{ }^{b}\end{array}$ & 17 & 3 \\
\hline
\end{tabular}

Notes: aOne case of asthma and drug eruption occurred in the same patient, which led to withdrawal. ${ }^{\mathrm{b}}$ These numbers refer to the number of AEs (the other categories in this table refer to the number of patients with AEs). Study I was a 4-week, randomized, placebo-controlled study that assessed the efficacy and tolerability of a supra-maximal dose of AZDI98I in patients with stable asthma.

Abbreviation: AEs, adverse events.
As the study was not powered to detect differences in efficacy between atopic and nonatopic patients, further research may be warranted in atopic patients to fully evaluate the potential clinical efficacy of AZD1981. Overall, AZD1981 was well tolerated across treatment groups, with similar incidences of withdrawal in the AZD1981 groups vs placebo. The proportions of patients experiencing AEs were similar between treatment groups, except for the $1,000 \mathrm{mg}$ group, where a slightly higher incidence of gastrointestinal disorders was reported.

Although the results of study 1 did not show a significant improvement in the primary outcome, taking into account the small sample size, the low level of symptoms, and the short study duration, the $9.5 \mathrm{~L} / \mathrm{min}$ treatment difference vs placebo ( $P=0.086$ ) provided limited proof of principle for an effect of AZD1981 on morning PEF to justify the second trial.

In the second add-on study, there was again no significant effect of any dose of AZD1981 when added to ICS on the primary efficacy variable of morning PEF. Numerically, the improvements vs placebo were of similar magnitude to that in study $1(8.5-12 \mathrm{~L} / \mathrm{min}$ at all three doses, with no doseresponse evident). There are a number of possible reasons for the studies for not reaching their primary end points. The lack of response could be due to the low number of patients in each group or the short duration of the trial, especially as steady state drug concentrations were only achieved after 2 weeks in study 1 . These studies were only 4 weeks in duration as toxicology studies had not been performed to assess the safety of AZD1981 for longer durations. Another reason for the negative responses could be that the standard deviation for morning PEF measurements in study 2 was also found to be higher than planned (planned $=45 \mathrm{~L} / \mathrm{min}$, study $2=57 \mathrm{~L} / \mathrm{min}$ ). This could be attributed to patients' varying background medication, the inclusion of current smokers in the trial, the short treatment period, or technical and/or handling problems with the peak flow meter. 
Table 6 Summary of AEs reported in study 2

\begin{tabular}{|c|c|c|c|c|}
\hline \multirow[t]{2}{*}{ Event } & \multicolumn{3}{|l|}{ AZDI98I } & \multirow[t]{2}{*}{ Placebo $(n=91)$} \\
\hline & $50 \mathrm{mg}$ bid $(\mathrm{n}=95)$ & $400 \mathrm{mg}$ bid $(n=90)$ & I,000 mg bid $(n=92)$ & \\
\hline Any $\mathrm{AE}$ & $28(29)$ & $22(24)$ & $33(36)$ & $24(26)$ \\
\hline \multicolumn{5}{|l|}{ AEs reported by $\geq 2 \%$ of patients } \\
\hline Asthma & $2(2)$ & $\mathrm{I}(\mathrm{I})$ & $3(3)$ & $4(4)$ \\
\hline Gastritis & $\mathrm{I}(\mathrm{I})$ & $2(2)$ & $5(5)$ & $3(3)$ \\
\hline Headache & $2(2)$ & $4(4)$ & $3(3)$ & $2(2)$ \\
\hline Upper respiratory tract infection & $4(4)$ & I (I) & 0 & $3(3)$ \\
\hline Withdrawals due to AEs & $3(3)$ & $2(2)$ & $5(5)$ & $4(4)$ \\
\hline Asthma & $\mathrm{I}(\mathrm{I})$ & $\mathrm{I}(\mathrm{I})$ & $I(I)$ & $2(2)$ \\
\hline Diarrhea & 0 & $\mathrm{I}(\mathrm{I})$ & 0 & 0 \\
\hline Rash & 0 & 0 & $\mathrm{I}(\mathrm{I})$ & 0 \\
\hline Pyoderma & 0 & 0 & $I(I)$ & 0 \\
\hline Nephrolithiasis & 0 & 0 & $I(I)$ & 0 \\
\hline Headache & $I(I)$ & 0 & 0 & 0 \\
\hline Gastrointestinal infection & $\mathrm{I}(\mathrm{I})$ & 0 & 0 & 0 \\
\hline Dyspnea & 0 & 0 & 0 & $\mathrm{I}(\mathrm{I})$ \\
\hline Cholelithiasis & 0 & 0 & $\mathrm{I}^{\mathrm{a}}(\mathrm{I})$ & 0 \\
\hline Abdominal discomfort & 0 & 0 & 0 & $\mathrm{I}(\mathrm{I})$ \\
\hline Abdominal pain & 0 & 0 & $\mathrm{I}^{\mathrm{a}}(\mathrm{I})$ & 0 \\
\hline $\begin{array}{l}\text { Number of AEs considered causally } \\
\text { related to treatment }{ }^{b}\end{array}$ & 6 & II & 24 & II \\
\hline
\end{tabular}

Despite study 2 not reaching its primary end point, there were positive effects on clinic $\mathrm{FEV}_{1}$ and asthma control assessed at the clinic using the ACQ-5 scores. These clinicrelated outcomes, in contrast to all patient-reported secondary outcomes, showed signs of efficacy with AZD1981 as an add-on therapy to ICS vs placebo. Moreover, any trends for efficacy seen in the clinic-assessed outcomes were even more pronounced in a post hoc analysis of patients with atopic asthma ( $72 \%$ of the total group). Overall, it appears that while patient-reported outcomes (eg, morning PEF) failed to show any robust efficacy for AZD1981, assessments supervised at the clinic (eg, $\left.\mathrm{FEV}_{1}\right)$ in study 2 did provide limited evidence of a benefit. A limitation of the study was an inability to detect any dose-response with AZD1981 across a 20-fold dose range, highlighting that further dose ranging would be needed at doses up to an order of magnitude lower than investigated in this study.

Given these findings, we speculate that the CRTh2 receptor may still be an important potential therapeutic target. The CRTh2 receptor antagonist OC000459 inhibited allergic inflammation induced by allergen challenge in steroid-naive patients with asthma ${ }^{27}$ and improved lung function in patients not using ICS. ${ }^{28}$ Moreover, the proinflammatory effects of prostaglandin $\mathrm{H}(1)$ were diminished in the presence of the CRTh2 receptor-specific antagonist TM30089. ${ }^{29}$ However, a dual antagonist of human D prostanoid and CRTh2,
AMG 853, has shown no effect on asthma control outcomes in a small trial of patients with moderate-to-severe asthma on ICS..$^{30}$ Isoquinoline derivatives are also being investigated as potential CRTh2 receptor antagonists. ${ }^{31}$ It may be argued that, as an add-on anti-inflammatory, the key benefit of CRTh2 receptor antagonists may be in preventing inflammation-driven exacerbations, which could not be properly assessed in either of the short-term trials performed with AZD1981, OC000459, or AMG 853. Indeed, the major efficacy benefit of increasing the dose of ICS or adding complementary anti-inflammatory therapy to high-dose ICS is the prevention of asthma exacerbations. Based on this, and the fact that increased efficacy was suggested in atopic patients in study 2, targeting CRTh2 receptor antagonists at patients with atopic disease may be warranted. In addition, the association of $\mathrm{PGD}_{2}$ and CRTh2 with severe allergic asthma suggests that further studies may be needed in this patient population. ${ }^{8}$

\section{Conclusion}

There was a nonsignificant effect of AZD1981 on the primary efficacy variable, morning PEF, after 4 weeks of treatment in patients with stable asthma without concomitant ICS or in patients with uncontrolled asthma with concomitant ICS. The slightly greater effects of AZD1981 in asthma control and $\mathrm{FEV}_{1}$ assessed at the clinic compared with placebo in 
an atopic group of patients may warrant further research to fully evaluate the potential of AZD1981.

\section{Acknowledgments}

The authors would like to thank Christer Hultquist and Bengt Larsson from AstraZeneca for their contribution to the research. The authors also thank Dr Elizabeth Hutchinson of Fishawack Communications Ltd, who provided medical writing services funded by AstraZeneca. This study was sponsored by AstraZeneca.

\section{Disclosure}

PK reports receiving speaker fees from AstraZeneca, MSD, Boehringer Ingelheim, Pfizer, GSK, Novartis, Teva, Sandoz, Chiesi, Meda, Polpharma, Krka, Adamed, FAES, Allergopharma, and Stallergenes, and serving as a consultant for AstraZeneca, Novartis, MSD, Boehringer Ingelheim, Chiesi, Almirall, FAEs, Allergopharma, and ALK. GT was an employee of AstraZeneca during the planning and conduct of the study and during the preparation of the manuscript. LB reports no conflicts of interest in this work.

\section{References}

1. Global Initiative for Asthma (GINA). GINA Report, Global Strategy for Asthma Management and Prevention. 2016. Available from: http://ginasthma.org/2016-gina-report-global-strategy-for-asthmamanagement-and-prevention/. Accessed June 2016.

2. Rabe KF, Adachi M, Lai CK, et al. Worldwide severity and control of asthma in children and adults: the global asthma insights and reality surveys. J Allergy Clin Immunol. 2004;114(1):40-47.

3. Hirai $\mathrm{H}$, Tanaka $\mathrm{K}$, Yoshie $\mathrm{O}$, et al. Prostaglandin $\mathrm{D} 2$ selectively induces chemotaxis in Thelper type 2 cells, eosinophils, and basophils via seventransmembrane receptor CRTH2. J Exp Med. 2001;193(2):255-261.

4. Nagata K, Hirai H, Tanaka K, et al. CRTH2, an orphan receptor of T-helper-2-cells, is expressed on basophils and eosinophils and responds to mast cell-derived factor(s). FEBS Lett. 1999;459(2):195-199.

5. Nagata K, Tanaka K, Ogawa K, et al. Selective expression of a novel surface molecule by human Th2 cells in vivo. J Immunol. 1999;162(3): 1278-1286.

6. O'Byrne PM, Naji N, Gauvreau GM. Severe asthma: future treatments. Clin Exp Allergy. 2012;42(5):706-711.

7. Murray JJ, Tonnel AB, Brash AR, et al. Release of prostaglandin D2 into human airways during acute antigen challenge. $N$ Engl J Med. 1986; 315(13):800-804.

8. Fajt ML, Gelhaus SL, Freeman B, et al. Prostaglandin D(2) pathway upregulation: relation to asthma severity, control, and TH2 inflammation. J Allergy Clin Immunol. 2013;131(6):1504-1512.

9. Gervais FG, Cruz RP, Chateauneuf A, et al. Selective modulation of chemokinesis, degranulation, and apoptosis in eosinophils through the PGD2 receptors CRTH2 and DP. J Allergy Clin Immunol. 2001;108(6): 982-988.

10. Hirai H, Tanaka K, Takano S, Ichimasa M, Nakamura M, Nagata K. Cutting edge: agonistic effect of indomethacin on a prostaglandin D2 receptor, CRTH2. J Immunol. 2002;168(3):981-985.

11. Stubbs VE, Schratl P, Hartnell A, et al. Indomethacin causes prostaglandin $\mathrm{D}(2)$-like and eotaxin-like selective responses in eosinophils and basophils. J Biol Chem. 2002;277(29):26012-26020.

12. Shirasaki H, Kikuchi M, Kanaizumi E, Himi T. Accumulation of CRTH2-positive leukocytes in human allergic nasal mucosa. Ann Allergy Asthma Immunol. 2009;102(2):110-115.
13. Gyles SL, Xue L, Townsend ER, Wettey F, Pettipher R. A dominant role for chemoattractant receptor-homologous molecule expressed on T helper type 2 (Th2) cells (CRTH2) in mediating chemotaxis of $\mathrm{CRTH} 2{ }^{+} \mathrm{CD} 4{ }^{+} \mathrm{Th} 2$ lymphocytes in response to mast cell supernatants. Immunology. 2006;119(3):362-368.

14. Schuligoi R, Sturm E, Luschnig P, et al. CRTH2 and D-type prostanoid receptor antagonists as novel therapeutic agents for inflammatory diseases. Pharmacology. 2010;85(6):372-382.

15. Pettipher R, Hansel TT. Antagonists of the prostaglandin D2 receptor CRTH2. Drug News Perspect. 2008;21(6):317-322.

16. Xue L, Barrow A, Pettipher R. Interaction between prostaglandin D and chemoattractant receptor-homologous molecule expressed on Th2 cells mediates cytokine production by $\mathrm{Th} 2$ lymphocytes in response to activated mast cells. Clin Exp Immunol. 2009;156(1):126-133.

17. Xue L, Gyles SL, Wettey FR, et al. Prostaglandin D2 causes preferential induction of proinflammatory Th2 cytokine production through an action on chemoattractant receptor-like molecule expressed on Th2 cells. J Immunol. 2005;175(10):6531-6536.

18. Heinemann A, Schuligoi R, Sabroe I, Hartnell A, Peskar BA. Delta 12-prostaglandin J2, a plasma metabolite of prostaglandin D2, causes eosinophil mobilization from the bone marrow and primes eosinophils for chemotaxis. J Immunol. 2003;170(9):4752-4758.

19. Xue L, Barrow A, Pettipher R. Novel function of CRTH2 in preventing apoptosis of human Th2 cells through activation of the phosphatidylinositol 3-kinase pathway. J Immunol. 2009;182(12): $7580-7586$.

20. Lukacs NW, Berlin AA, Franz-Bacon K, et al. CRTH2 antagonism significantly ameliorates airway hyperreactivity and downregulates inflammation-induced genes in a mouse model of airway inflammation. Am J Physiol Lung Cell Mol Physiol. 2008;295(5):L767-L779.

21. Stebbins KJ, Broadhead AR, Correa LD, et al. Therapeutic efficacy of AM156, a novel prostanoid DP2 receptor antagonist, in murine models of allergic rhinitis and house dust mite-induced pulmonary inflammation. Eur J Pharmacol. 2010;638(1-3):142-149.

22. Uller L, Mathiesen JM, Alenmyr L, et al. Antagonism of the prostaglandin D2 receptor CRTH2 attenuates asthma pathology in mouse eosinophilic airway inflammation. Respir Res. 2007;8:16.

23. Diamant Z, Sidharta PN, Singh D, et al. Setipiprant, a selective CRTH2 antagonist, reduces allergen-induced airway responses in allergic asthmatics. Clin Exp Allergy. 2014;44(8):1044-1052.

24. Sidharta PN, Diamant Z, Dingemanse J. Single- and multiple-dose tolerability and pharmacokinetics of the CRTH2 antagonist setipiprant in healthy male subjects. Fundam Clin Pharmacol. 2014;28(6): 690-699.

25. Horak F, Zieglmayer P, Zieglmayer R, et al. The CRTH2 antagonist OC000459 reduces nasal and ocular symptoms in allergic subjects exposed to grass pollen, a randomised, placebo-controlled, double-blind trial. Allergy. 2012;67(12):1572-1579.

26. Luker T, Bonnert R, Brough S, et al. Substituted indole-1-acetic acids as potent and selective CRTh2 antagonists-discovery of AZD1981. Bioorg Med Chem Lett. 2011;21(21):6288-6292.

27. Singh D, Cadden P, Hunter M, et al. Inhibition of the asthmatic allergen challenge response by the CRTH2 antagonist OC000459. Eur Respir J. 2013;41(1):46-52.

28. Barnes N, Pavord I, Chuchalin A, et al. A randomized, double-blind, placebo-controlled study of the CRTH2 antagonist OC000459 in moderate persistent asthma. Clin Exp Allergy. 2012;42(1):38-48.

29. Schröder R, Xue L, Konya V, et al. PGH1, the precursor for the antiinflammatory prostaglandins of the 1 -series, is a potent activator of the pro-inflammatory receptor CRTH2/DP2. PLoS One. 2012;7(3): e33329.

30. Busse WW, Wenzel SE, Meltzer EO, et al. Safety and efficacy of the prostaglandin D2 receptor antagonist AMG 853 in asthmatic patients. J Allergy Clin Immunol. 2013;131(2):339-345.

31. Nishikawa-Shimono R, Sekiguchi Y, Koami T, et al. Isoquinoline derivatives as potent CRTH2 receptor antagonists: synthesis and SAR. Bioorg Med Chem Lett. 2012;22(9):3305-3310. 


\section{Publish your work in this journal}

Drug Design, Development and Therapy is an international, peerreviewed open-access journal that spans the spectrum of drug design and development through to clinical applications. Clinical outcomes, patient safety, and programs for the development and effective, safe, and sustained use of medicines are the features of the journal, which

has also been accepted for indexing on PubMed Central. The manuscript management system is completely online and includes a very quick and fair peer-review system, which is all easy to use. Visit http://www.dovepress.com/testimonials.php to read real quotes from published authors.

Submit your manuscript here: http://www.dovepress.com/drug-design-development-and-therapy-journal 